\title{
Ultrasonography Feature and Clinical Finding of Trisomy 13 (Patau Syndrome): A Case Report
}

\author{
Melissa Edelweishia, ${ }^{1}$ I Wayan Artana Putra ${ }^{2}$ \\ ${ }^{1}$ Specialist Program of Obstetric and Gynecology, ${ }^{2}$ Division of Fetomaternal Medicine \\ Department of Obstetric and Gynecology, Medical Faculty, Udayana University/ \\ Sanglah Hospital, Bali \\ Korespondensi: Melissa Edelweishia, Email: melissa.edelweishia@gmail.com
}

\begin{abstract}
Abstrack
Background: Trisomy 13 is a trisomy disorder of chromosome 13 which causes many fetal structural defects. The prognosis is very poor and the majority is still birth. Major structural anomalies are occasionally identified in the late-first or early-second trimester. Any discovery of multiple structural anomalies in the fetus increases the chances of chromosomal anomalies.

Case Report: Here we report trisomy 13 case of A 34-years-old housewife, third gravida, prenatal diagnosis during antenatal ultrasonography showed diaphragmatic hernias, cardiovascular dextroposition, ventricular septal defect, labiognatopalatoschizis and renal dextra pyeletaxis. From the chromosomal analysis, the fetal karyotype was 47 XY+13. A male infant was born with weight of 2600 grams, $46 \mathrm{~cm}$, cyanosis, and severe respiratory distress with congenital abnormalities of micrognathia, diaphragmatic hernia, dextrocardia, ventricular septal defect, persistent pulmonary hypertension of newborn, undescended testis, labiognatopalatoshizis, and polydactily.

Discussion: Prenatal diagnosis can be done through amniocentesis for karyotyping which is the gold standard for diagnosis trisomy 13. In addition, screening can also be done since the first trimester.

Conclusion: All pregnancies in second trimester must be evaluated for structural abnormalities through ultrasonography and cytogenetic examination if necessary for early diagnosed.
\end{abstract}

Key word: Congenital Abnormalities, Ultrasonography, Clinical Finding, Trisomy 13, Patau Syndrome

\section{Gambaran Ultrasonografi dan Klinis Kehamilan dengan Janin Trisomi 13 (Sindrom Patau): Laporan Kasus}

\begin{abstract}
Abstrak
Latar Belakang: Trisomi 13 merupakan kelainan jumlah kromosom 13 yang menyebabkan defek struktural pada fetus. Prognosisnya sangat buruk dan kebanyakan lahir mati. Kelainan struktural mayor sering teridentifikasi pada akhir trimester pertama atau awal trimester kedua. Setiap temuan kelainan struktural pada fetus berpotensi kelainan kromosom.

Laporan Kasus: Di sini akan dijelaskan kasus trisomi 13 yang didiagnosis prenatal dari wanita G3P1011, 34 tahun, terdiagnosis melalui pemeriksaan ultrasonografi. Antenatal scan dilakukan pada usia kehamilan 21 minggu dan gambaran ultrasonografi menunjukkan hernia diafragmatika, dextrokardia, ventricular septal defect, labiognatopalatoschizis dan pielektasis ginjal kanan. Kemudian dilanjutkan pemeriksaan kromosom melalui amniosintesis dan didapatkan hasil $47 \mathrm{XY}+13$. Bayi laki-laki lahir secara sectio secarea dengan berat 2600 gram, panjang badan $46 \mathrm{~cm}$, sianosis, asfiksia berat, kelainan kongenital micrognatia, hernia diafragmatika, dextrokardia, defek septum ventrikular, hipertensi pulmonal, labiognatopalatoshizis, dan polidactili.

Diskusi: Diagnosis prenatal dapat dilakukan melalui pemeriksaan amniosintesis bertujuan untuk melihat karyotyping yang merupakan gold standard untuk mendiagnosis trisomi 13. Selain itu, screening juga dapat dikerjakan sejak trimester pertama.

Kesimpulan: Semua kehamilan pada trimester kedua harus dievaluasi kelainan struktural melalui ultrasonografi dan bila perlu pemeriksaan sitogenetik sehingga dapat mendiagnosis lebih awal.
\end{abstract}

Kata kunci: Kelainan Kongenital, Ultrasonografi, Klinis, Trisomi 13, Patau Sindrom. 


\section{Introduction}

Trisomy 13 or Patau syndrome is a trisomy disorder. It is due to the presence of a whole extra copy of chromosome 13 . Trisomy 13 is the third most common autosomal trisomy, after trisomy 21 (Down syndrome) and 18 (Edwards syndrome) with the prevalence of birth in region of 1 in 5,000 to 1 in 20,000. The incidence of trisomy 13 varies across countries in Europe, America and Asia. In Asia, for example in Malaysia, the incidence of congenital anomalies is 1 in 838 live births. The incidence of trisomy 13 is 2.6 per 10,000 births. The poor prognosis that exists for infants born with trisomy 13, Patau syndrome, has been well known and documented over the last forty years. It is also clear that the survival rates for this condition has not changed greatly during that time period. What has changed dramatically during this period of time is the ability to diagnose trisomy 13 prenatally, using ultrasound clinically indicated screening or assesstment, and invasive diagnostic testing such as chorionic villous sampling and amniocentesis. ${ }^{1,2}$

In recent years, there appears to be a significant increase in the prevalence of pregnancies with trisomy 13, this may be related to an increase in maternal age observed in many developed countries. As this is generally a lethal condition, when confronted with this diagnosis prenatally, it is important to counsel parents accurately about the ultimate prognosis, and likelihood of intrauterine, neonatal or infant death, or long-term survival. ${ }^{1,3}$

There are no known risk factors of trisomy 13 except previous history of any affected fetus. So suspicion only occurs during routine second-trimester ultrasound scanning showing multiple fetal structural anomalies confirmed by cytogenetic examination, which may reveal the diagnosis. Among structural anomalies, $80 \%$ are cardiac defects which include patent ductus arteriosus, ventricular septal defect, atrial septal defect, and dextrocardia. ${ }^{3}$

The prognosis of infants with trisomy 13 is very poor and the majorities are still birth. Some infants are born but do not last long. Approximately $80 \%$ of live-born infants die on the first day, and the mortality rate of neonatal death within 1 week of life is more than $90 \% .{ }^{3}$ Some infants survived in the first six-months usually die of heart failure or concurrent infection. Most died before age of one year; less than $10 \%$ can survive in the first year. ${ }^{2}$

\section{Case Report}

A 34-years-old Balinese housewife, a third gravida with 1 child alive and previous pregnancies with intrauterine death. It was a planned pregnancy and her LMP was on September 16, 2017. Antenatal examination was performed at 21 weeks of pregnancy revealed multiple structural abnormalities as diaphragmatic hernias, cardiovascular dextroposition, ventricular septal defect, labiognatopalatoschizis and renal dextra pyeletaxis. For this reason, she was advised amniocentesis for karyotyping. She did amniocentesis and karyotyping on March 27, 2018 (27 weeks of gestation) showing 47Y + 13. Due to multiple congenital anomalies in the fetus, multidiciplinary approached with neonatology, cardiology and pediatric surgery divisions was performed. It is planned for sectio cesarean at 37 weeks of gestation with the expectation to correct the diaphragmatic hernia for saving the baby's life.

Previous history of pregnancy, the first child was delivered vaginally in 2011 at term with birth weight 3200 grams, and the second one was stillbirth in 2016. She had no medical history or in any treatment.

On June 2, 2018, patient came to the emergency ward of Sanglah Hospital and complained of labor pain. Physical 

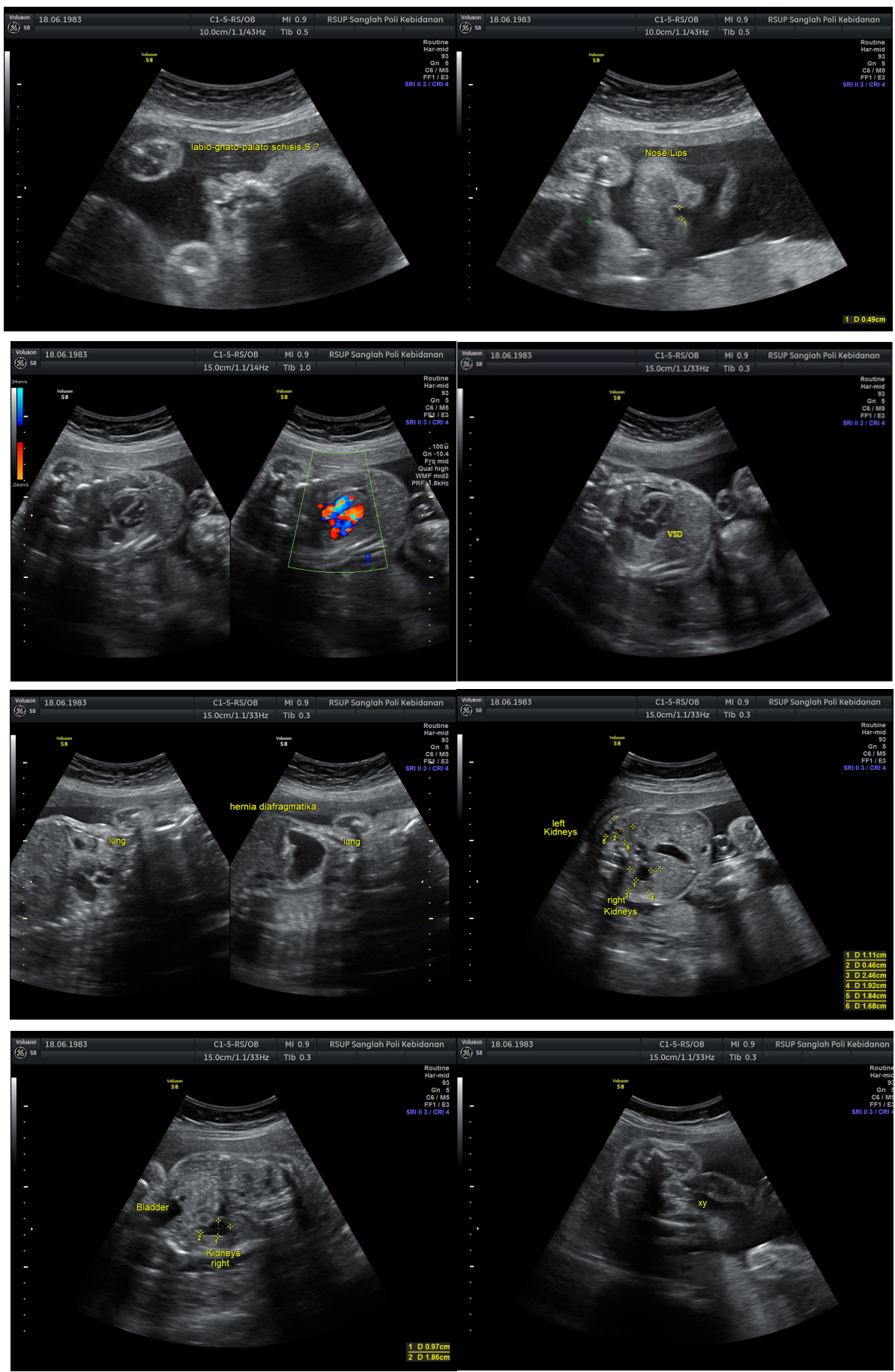

Figure 1 Ultrasonography scan of second trimester with labiognatopalatoskizis, VSD, diafragmatic hernia, pyelektasis renal dextra

examination showed her body weight was $70 \mathrm{~kg}$, BMI was $27.3 \mathrm{~kg} / \mathrm{m} 2$, blood pressure $120 / 80 \mathrm{mmHg}$, and pulse rate $80 \mathrm{bpm}$. Obstetric examination showed symphysiofundal height of $28 \mathrm{~cm}$, single fetus in longitudinal lie, cephalic presentation, and fetal heart rate of $165 \mathrm{bpm}$. It was also found uterine contraction of 3-4 times in 10 minutes with duration of 30-40 seconds. From vaginal toucher examination, cervix dilatation 
was $2 \mathrm{~cm}$. Emergency section secarea was performed. At 6:19 pm, a male infant was born with weight of 2600 grams, $48 \mathrm{~cm}$ in length, and head circumference of $32 \mathrm{~cm}$, cyanosis, $\mathrm{SaO} 260 \%$, and hypotonic. On auscultation, the heart rate was 55 beats per minute, the systolic murmur on parasternal line dextra, the bowel sounds in left hemithorax. Further, it was noted that he had micrognathia, diaphragmantic hernia, dextrocardia, ventricular septal defect, persistent pulmonary hypertension of newborn, undecended testis, labiognatopalatoshizis, and polydactily.

In postnatal period, maternal blood pressure increased postsurgery with blood pressure of $150 / 100 \mathrm{mmHg}$, then urinalysis showed proteinuria (-).

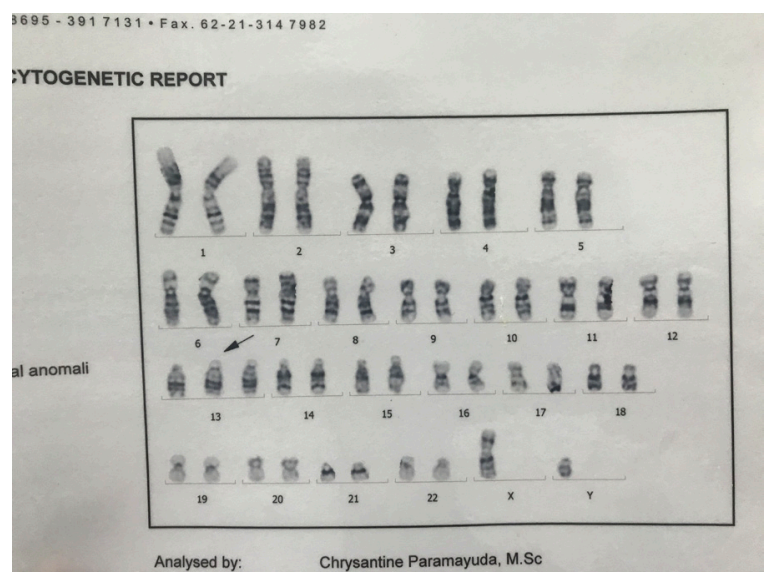

Figure 2 Cytogenetic result showed kariotype of trisomy 13
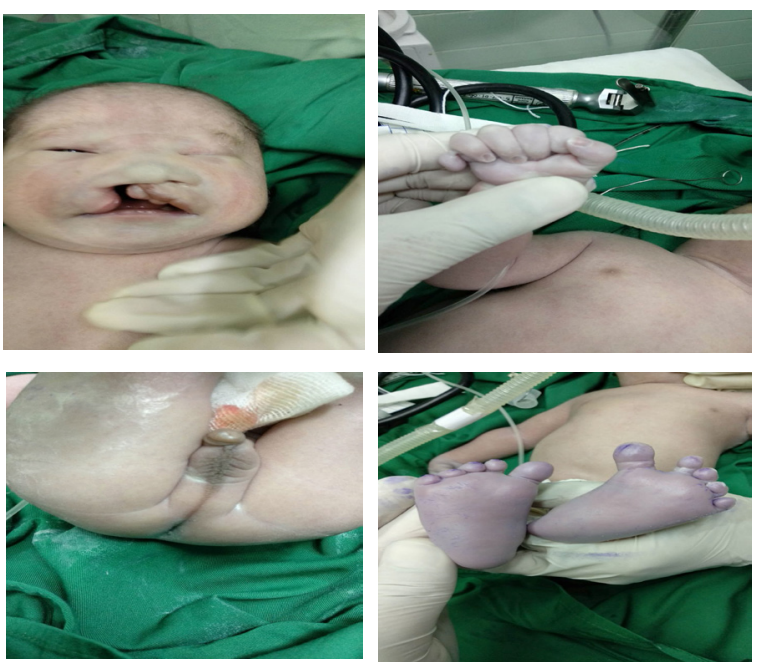

Figure 3 Congenitalanomalywithmicrognathia, labiognatopalatoskizis, polydactily, and undescended testis.

\section{Discussion}

Trisomy 13 occurs due to non-disjunction during meiotic division. Trisomy 13 can be diagnosed prenatally. Prenatal diagnosis is performed when pregnancy has a risk of congenital abnormalities in the fetus, especially history of having children with congenital abnormalities and increasing maternal age. ${ }^{5,6,7}$

The prenatal diagnosis of trisomy 13 involves first and second trimester screening and by invasive diagnostic methods such as chorionic villus sampling (CVS) or amniocentesis. ${ }^{8}$ Amniocentesis was performed for karyotyping study. Karyotyping is the gold standard for diagnosing trisomy 13. ${ }^{12}$ To minimize the number of procedures, screening can be done by non-invasive methods that include ultrasound and biochemical analysis of maternal serum can be done since the first trimester. ${ }^{6,7}$

In this case, there was a risk factor of previous intrauterine fetal death (IUFD). So initial screening is needed since the first trimester to find out any chromosomal 
abnormalities. This patient examined her pregnancy in the second trimester where the ultrasonography showed labiognatopalatoskizis, ventricular septal defect, diaphragmatic hernia, and pyeletaksis renal dextra. To establish a definitive diagnosis of whether the fetus has chromosomal abnormalities, amniocentesis was needed. Due to the limited facilities in karyotyping examination in our center, samples were sent to more adequate laboratory and the result was $47 \mathrm{XY}+13$ suitable for trisomy 13 after the baby was born.

After the diagnosis of trisomy 13 is established, the management of pregnancy varies according to the gestational age at that time. At pre-viable gestational age, termination of pregnancy is an option. As the pregnancy has developed, attention should be focused on the method of labor. The decision about the method of delivery is determined by obstetrical considerations and does not depend on the presence of the syndrome. Cesarean delivery is not recommended due to lethal condition. The entire management plan should include discussion with neonatologist on neonatal resuscitation procedures, cost, and alternatives to aggressive resuscitation. ${ }^{2}$

In our cases, the couple was counseled about the prognosis. The parents decided to continue the pregnancy. Based on congenital abnormalities from ultrasonography in these patients, a multidisciplinary discussion with neonatology, cardiology and pediatric surgery about the appropriate method of delivery was performed, and it was decided to do a cesarean delivery with expectation we could do correction of diaphragmatica hernia soon after the baby was born to prevent lung hypoplasia.

A multi-state, population-based study in 16 European countries on 240 live-born infants with trisomy 13 showed that the prevalence of anomalies were as follows: cardiac anomalies 57\%; nervous system anomalies 39\%; eye anomalies $30 \%$; polydactyly $44 \%$; and orofacial cleft $45 \% .{ }^{9}$ Among the structural anomalies, $80 \%$ are cardiac defects which include patent ductus arteriosus, ventricular septal defect, atrial septal defect and dextrocardia. ${ }^{3}$ Other disorders include neural tube defects, especially cephalocele, microphthalmia, cleft lip and palate, omphalocele, cystic dysplasia of the kidneys, polydactyly, rocker-bottom feet, and aplasia of the skin area. ${ }^{2}$

In this case, a male baby with severe asphyxia was born. On examination, the baby wasnoted tohavemultipledysmorphicfeatures consistent with Patau syndrome, including micrognathia, labiognatopalatoshizis, diaphragmatic hernia, dextrocardia, asianotic congenital heart disease of ventricular septal defect, persistent pulmonary hypertension of newborn, undecensus testis, and polydactily. Congenital heart defects are frequent among patients with trisomy 13 and echocardiography should be offered to all individuals, even to those without cardiac symptoms. The most common defects is septal defect. The survival time also does not seem to be different between patients with and without septal defects. ${ }^{12}$ This clinical sign showed trisomy 13 and had been proved by cytogenetic analysis from amniocentesis. Medical problems after birth depend on congenital abnormalities. For example, respiratory difficulty is due to pulmonary developmental disorder. ${ }^{8}$ In this case, cardiac echocardiography showed pulmonary hypertension, ventricular septal defect, a small defect in the atrial, and patent ductus arteriosus.

Women who are carrying a trisomy 13 fetus are prone to have abnormal placenta as well as to develop preeclampsia in the second and third trimesters. The placental abnormalities associated with trisomy 13 such as small placental volume and reduced placental vascularization, will result in placental hypoxia and produce sFlt1, then excessive expression of sFlt1 resulting in preeclampsia. ${ }^{2,10,11}$ In this case, the patient 
regularly doing antenatal care every month since second trimester and there is no increasing of blood pressure. However, after delivery there was a significant increase of blood pressure that led to the condition of preeclampsia.

The prognosis of infants with trisomy 13 is very poor and the majority of babies are still birth. More than $80 \%$ of children with trisomy 13 died in the first year. Some babies survived the first six months usually die because of heart failure or concomitant infections. ${ }^{2,13}$ In this case the infant was born with severe asphyxia conditions accompanied by multiple congenital abnormalities. Due to respiratory failure, the baby was intubated and mechanically ventilated on neonatal intensive care unit (NICU). Neonates with this syndrome die usually within few hours or days of life. So did this baby, survived only for 4 days.

\section{Conclusion}

Trisomy 13 is a lethal condition. The initial diagnosis of this syndrome is important for proper management of the patient, including monitoring of specific complications. All pregnancies in the second trimester should be evaluated for structural abnormality through ultrasound. Even if cytogenetic examination is necessary, it should be done as soon as possible. Screening is important, especially in high-risk pregnancies such as maternal age $>35$ years and history of having fetus with congenital abnormalities. Once a diagnosis of Patau syndrome is made, discussions about pregnancy management and treatment options for neonates with this syndrome are urgently needed and should be determined immediately if the pregnancy is to be continued through prenatal counseling to parents with obstetricians, neonatologists, clinical geneticists, surgeons, and genetic counselors for the treatment and survival of infants. Regarding future pregnancy, parents should be referred to a geneticist or genetic counselor for appropriate counseling regarding recurrent risks, etiology and prognosis. Recurrent risks depend on the details of the chromosome abnormality and maternal age.

\section{Reference}

1. Barry SC, Walsh CA, Burke AL, McParland P, McAuliffe FM, Morrison JJ. Natural history of fetal trisomy 13 after prenatal diagnosis. Am J Med Genet A. 2015 Jan;167A(1):147-50.

2. Pawelec M, Dżugalik $M$, Pietras J, Bełza Ł, Latkowski Ł. Medical and ethical considerations related to viable fetuses with trisomy 13 in the $36^{\text {th }}$ week of pregnancy-A review of the literature. Adv Clin Exp Med. 2015 SeptOct;24(5):911-921.

3. Laila TR, Thangarajah TT, Ahmed SS, Shahruddin SI, Apparudai U, Razali NA. Patau syndrome: A case report. Sch J Med Case Rep. 2017;5(3):174-6.

4. Best RG, Gregg AR. Patau Syndrome [Internet]. Medscape. 2017 [cited 11 June 2018]. Available from: http://emedicine. medscape.com/article/947706

5. Bulagouda RS, Bannur BM, Keerti K, Patil BS, Kadakol GS. Patau syndrome [Partial trisomy]: A case study. Int $\mathrm{J}$ Pharm Bio Sci. 2017 Apr;8(2): (B)799805.

6. Cook JP. Investigating clustering in trisomy 18 and trisomy 13 [thesis]. London: Queen Mary University of London; 2014.

7. Hall MP, Hill M, Zimmermann B, Sigurjonsson S, Westemeyer M, Saucier $\mathrm{J}$, et al. Non-invasive prenatal detection of trisomy 13 using a single nucleotide polymorphism- and informatics-based approach. PLoS ONE. 2014 May;9(5): e96677. 
8. Lad SL, Soon R, Weng, MH. Antenatal sonographic diagnosis of Patau syndrome (Trisomy 13): A case report. Indian Journal of Obstetrics and Gynecology Research. 2016;3(3):297-9.

9. Springett A, Wellesley D, Greenlees R, et al. Congenital anomalies associated with trisomy 18 or trisomy 13: A registrybased study in 16 European countries, 2000-2011. Am J Med Genet Part A. 2015; 167A:3062-3069.

10. Nikuei P, Malekzadeh K, Rajaei M, Nejatizadeh A, Ghasemi N. The imbalance in expression of angiogenic and anti-angiogenic factors as candidate predictive biomarker in preeclampsia.
Iran J Reprod Med. 2015 May;13(5):25162.

11. Chen CP. Placental abnormalities and preeclampsia in trisomy 13 pregnancies. Taiwan J Obstet Gynecol. 2009 Mar;48(1):3-8.

12. Polli JB, Groff DdP, Petry P, et al. Trisomy 13 (Patau Syndrome) and Congenital Heart Defects. Am J Med Genet Part A. 2014.;164A:272-275.

13. Szili K. New aspects and the integration of the first and early second trimester screening to the feto-maternal medicine [thesis]. Szeged: University of Szeged; 2015 